\title{
Struktur Modal, Ukuran Perusahaan, Likuiditas dan Profitabilitas Perusahaan Manufaktur yang Listing di BEI
}

\author{
Susiyanti \\ Matana University \\ Tangerang Indonesia \\ Susiyanti016@gmail.com
}

\author{
Bahtiar Effendi \\ Matana University \\ Tangerang Indonesia \\ bahtiar.effendi@matanauniversity.ac.id
}

\begin{abstract}
This study aims to determine the effect of capital structure, firm size and liquidity on profitability in manufacturing companies food and beverage sub-sector listed on the stock exchange Indonesia. This study uses a quantitative approach. Data collection techniques used in this study is the method of documentation that is by collecting and recording financial statements. Sources of data used are secondary data in the form of financial statements of food and beverage manufacturing companies listed on the BEI period 2014-2016 which can be obtained through the website www.idx.co.id. The sampling technique used is purposive sampling with the number of respondents 13 companies. The method of data analysis used is multiple regression linear regression analysis using SPSS 24.0 program aid. The result of research indicates that (1) partially capital structure has a significant negative effect on profitability, (2) firm size has significant positive effect on profitability, (3) liquidity has significant negative effect on profitability, (4) simultaneously capital structure, firm size, and liquidity has a significant influence on the profitability of manufacturing companies food and beverage sub-sector listed in Indonesia stock exchange.
\end{abstract}

Keywords : Capital Structure, Firm Size, Liquidity, Profitability.

\section{PENDAhuluan}

Struktur modal yang diukur dengan DER terjadi penurunan pada tahun 2012 sebesar $0,42 \%$, dan ROA mengalami peningkatan sebesar $0,11 \%$. Hal ini sejalan dengan hasil penelitian Fitri Linda Rahmawati (2009) yang menyatakan DER berpengaruh negatif terhadap ROA. Namun, pada tahun 2013 ROA mengalami penurunan sebesar $0,07 \%$, sedangkan DER mengalami penurunan sebesar 3,62\%. Hal ini tidak sejalan dengan hasil penelitian Dewi, et al., (2015) yang menyatakan DER berpengaruh negatif terhadap ROA. Maka disini terjadi kesenjangan antara teori dengan kenyataan yang terjadi (Effendi dan Khamdevi, 2017). Ukuran perusahaan manufaktur pada tahun
2005 adalah 13,92. Sedangkan pada tahun 2006 mengalami kenaikan menjadi 13,98. Kenaikanpun kembali terjadi pada tahun 2007 sebesar 14,12. Peningkatan juga terjadi pada tahun 2008 dan 2009 yang masingmasing adalah peningkatan sebesar 14,35 dan 14,44 (Nugroho, 2011). Tahun 2012 likuiditas sebesar 2,13kali dengan profitabilitas 10,57\%. Tahun 2013 likuiditas mengalami penurunan sebesar 0.09 kali, namun profitabilitas mengalami penurunan sebesar $1,17 \%$. Hal ini tidak sesuai dengan teori yang dikemukakan oleh Horne \& Wachowicz (2009), bahwa likuiditas berbanding terbalik dengan profitabilitas. Semakin rendah likuiditas perusahaan maka kemampuan perusahaan untuk menghasilkan laba semakin tinggi. Tahun 2014 likuiditas 
mengalami peningkatan sebesar 0,18 kali, sedangkan profitabilitas kembali mengalami penurunan sebesar $1,78 \%$ (Sariyana, et al., 2016).

\subsection{Rumusan Masalah}

Permasalahan penelitian adalah apakah struktur modal (DER), ukuran perusahaan, likuiditas (CR) berpengaruh terhadap profitabilitas (ROA)?.

\subsection{Tujuan Penelitian}

Berdasarkan permasalahan yang telah diuraikan di atas, maka tujuan penelitian ini adalah untuk mengetahui pengaruh struktur modal (DER), terhadap profitabilitas (ROA), ukuran perusahaan (size), likuiditas (CR) terhadap profitabilitas (ROA)?

\section{KAJIAN PUSTAKA}

\subsubsection{Trade-off Theory}

Trade-off Theory menyatakan bahwa perusahaan menyeimbangkan manfaat dari 17 pendanaan dengan hutang dengan suku bunga dan biaya kebangkrutan yang lebih tinggi. Trade-off Theory memprediksi perusahaan akan memilih hutang sebagai sumber dana asal manfaat dari tambahan hutang masih lebih besar dibandingkan dengan kerugiannya. Penggunaan hutang akan meningkatkan nilai perusahaan tetapi hanya sampai titik tertentu, setelah titik tersebut penggunaan hutang justru menurunkan nilai perusahaan karena kenaikan nilai keuntungan dari penggunaan hutang tidak sebanding dengan kenaikan biaya financial distress dan agency cost. Menurut Trade-off Theory, struktur modal yang optimal dapat tercapai dengan menyeimbangkan keuntungan perlindungan pajak dengan beban biaya sebagai penggunaan hutang yang semakin besar (Sjahrial, 2009).

\subsubsection{Pecking Order Theory}

Pecking Order Theory ditemukan oleh Myers pada tahun 1984 yang dibangun berdasarkan asumsi dan temuan empiris tentang perilaku keuangan perusahaan dimana Myers memberikan penjelasan atas temuan pecking order dengan landasan asumsi adanya asymmetric information. Asymmetric information dapat diartikan bahwa ketika manajer menemukan kesempatan investasi yang bagus (NPV-nya tinggi), dia tidak dapat menyampaikan informasi tersebut ke investor luar kerena investor luar tidak percaya. Alasan pengambilan teori trade-off dan pecking order theory dalam penelitian ini, karena kedua teori ini sering digunakan oleh penelitian terdahulu, dan adanya hubungan yang berkaitan dengan variabel-variabel dalam penelitian ini.

\subsection{Pengembangan Hipotesis}

\subsubsection{Keterkaitan Struktur Modal} Terhadap Profitabilitas

Aprilia dan Effendi (2019) dan Effendi (2019) menyatakan bahwa financial distress merupakan faktor penentu dari penentuan opini kualitas pemeriksaan laporan keuangan Hubungan struktur modal terhadap profitabilitas menurut Dewi, et al., (2015) struktur modal (DER) secara parsial berpengaruh negatif dan signifikan terhadap profitabilitas (ROA). Sedangkan menurut Bonatua, et al., (2015) menyimpulkan bahwa Debt to Equity Ratio (DER) secara simultan berpengaruh signifikan positif terhadap Return On Assets (ROA). Debt to Equity Ratio (DER) secara parsial berpengaruh signifikan positif terhadap Return on Assets (ROA). Dari pembahasan masalah diatas, maka peneliti mengajukan hipotesis berdasarkan penelitian Bonatua, et al., (2015) yaitu, sebagai berikut :

$\mathbf{H}_{1}$ : Struktur modal berpengaruh positif terhadap profitabilitas.

\subsubsection{Keterkaitan Ukuran Perusahaan Terhadap Profitabilitas}

Ambarwati, et al., (2015) menyimpulkan bahwa ukuran perusahaan berpengaruh positif signifikan terhadap profitabilitas. Hal ini menjelaskan bahwa semakin besar ukuran perusahaan, maka semakin besar probabilitas untuk melakukan peningkatan laba (Effendi, 2018). Selanjutnya, Sekarwigati dan Effendi (2019), Effendi (2017) menyatakan bahwa ukuran perusahaan bisa dilihat dari total asset perusahaan, karena perusahaan dengan total asset yang besar mencerminkan kemapanan perusahaan. Sedangkan menurut Putra, et al., 
(2015) menyimpulkan bahwa ukuran perusahaan berpengaruh negatif dan tidak signifikan terhadap profitabilitas pada perusahaan Industri makanan dan minuman di BEI. Dari pembahasan masalah diatas, maka peneliti mengajukan hipotesis berdasarkan penelitian Ambarwati, et al., (2015) yaitu, sebagai berikut :

$\mathbf{H}_{\mathbf{2}}$ : Ukuran perusahaan berpengaruh positif terhadap profitabilitas.

\subsubsection{Keterkaitan Likuiditas dengan Profitabilitas}

Sariyana, et al., (2016) menyimpulkan likuiditas berpengaruh negatif dan signifikan secara parsial terhadap profitabilitas (studi pada perusahaan food and beverages yang terdaftar di Bursa Efek Indonesia periode 2012-2014). Hasil penelitian ini didukung oleh Ratnasari, et al., (2016) berdasarkan perhitungan dengan menggunakan SPSS didapatkan nilai tingkat signifikan sebesar 0.239, dimana tingkat signifikan lebih besar dari level alpha sebesar 0.05, sehingga didapatkan kesimpulan bahwa variabel likuiditas berpengaruh tidak signifikan terhadap profitabilitas, sehingga hipotesis yang diajukan ditolak. Dari pembahasan masalah diatas, maka peneliti mengajukan hipotesis berdasarkan penelitian Sariyana, et al., (2016) yaitu, sebagai berikut:

$\mathbf{H}_{3}$ : Likuiditas berpengaruh negatif terhadap profitabilitas.

Gambar 1. menjelaskan hubungan empiris antara struktur modal, ukuran perusahaan dan likuiditas terhadap profitabilitas.

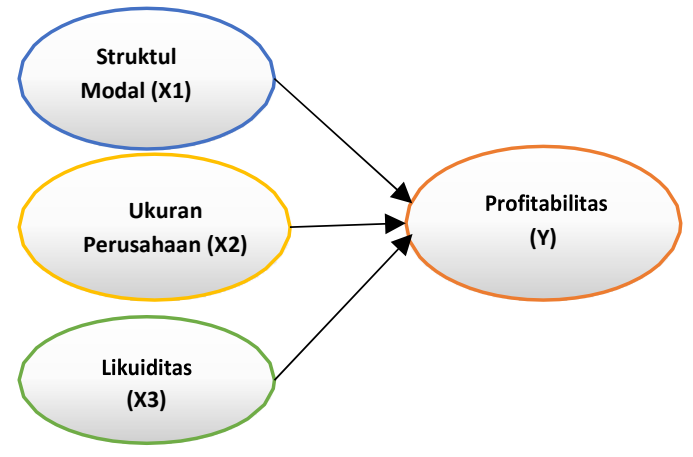

Gambar 1. Model Empiris

\section{METODE PENELITIAN}

Populasi dalam penelitian ini adalah seluruh perusahaan sektor makanan dan minuman yang terdaftar Bursa Efek Indonesia (BEI) tahun 2014-2016. Berdasarkan teknik purposive sampling, diperoleh sampel sebanyak 13 sub sektor makanan dan minuman yang terdaftar di Bursa Efek Indonesia (BEI) dengan periode waktu dari tahun 2014 sampai dengan tahun 2016.

Uji hipotesis dilakukan dengan cara uji signifikansi (pengaruh nyata) variabel independen $(\mathrm{X})$ terhadap variabel dependen (Y). Dalam penelitian ini digunakan analisis regresi linear berganda. Analisis regresi digunakan oleh peneliti apabila bermaksud meramalkan bagaimana keadaan (naikturunnya) variabel dependen, dan apabila dua atau lebih variabel independen sebagai prediktor dimanipulasi atau dinaik turunkan nilainya. Untuk pengujian hipotesis yaitu dengan menggunakan analisis regresi berganda, berikut model regresi tersebut:

$$
\mathrm{Y}=\alpha+\beta 1 \mathrm{DER}+\beta 2 \mathrm{Size}+\beta 3 \mathrm{CR}+\mathrm{e}
$$

Keterangan Persamaan Regresi Berganda pada tabel 3.1 berikut ini:

Tabel 3.1

Penjelasan Persamaan Regresi Berganda

\begin{tabular}{|l|l|}
\hline Simbol & Keterangan \\
\hline $\mathrm{Y}$ & Profitabilitas (ROA) \\
$\alpha$ & Konstanta \\
$\beta 1-\beta 3$ & Koefisien Parameter Struktur \\
DER & Modal Ukuran Perusahaan \\
Size CR & Likuiditas (Current Ratio) \\
$\mathrm{e}$ & Kesalahan Pengganggu \\
& (disturbance's error) \\
& \\
\hline
\end{tabular}

IV. HASIL DAN PEMBAHASAN

\begin{tabular}{|l|c|c|c|c|c|c|}
\hline & $\mathrm{N}$ & Minimum & Maximum & \multicolumn{2}{|c|}{ Mean } & Std \\
\cline { 2 - 7 } & $\begin{array}{c}\text { Statisti } \\
\mathrm{c}\end{array}$ & Statistic & Statistic & Statistic & Std. Error & Statistic \\
\hline DER & 35 & .7288874773 & 4.483590759 & 1.967537114 & .2475154032 & 1.464320873 \\
Size & 35 & 12.00156882 & 12.98447599 & 12.49837305 & .0464396913 & .2747409186 \\
CR & 35 & 1.382336194 & 3.333547041 & 2.121517961 & .0957024126 & .5661831083 \\
ROA & 35 & .0412108584 & .3345319178 & .1494255353 & .0158351721 & .936821417 \\
Valid N & 35 & & & & & \\
(listwise) & & & & & & \\
\hline
\end{tabular}




\subsection{Hasil Analisis Statistik Deskriptif}

Tabel di atas merupakan hasil analisis statistik deskriptif. Berdasarkan tabel tersebut dapat dijelaskan bahwa:

1. Terdapat $\mathrm{N}$ yang merupakan banyaknya sampel penelitian, yaitu sebanyak 35 sampel perusahaan manufaktur sub sektor makanan dan minuman yang terdaftar di Bursa Efek Indonesia (BEI) periode 2014-2016.

2. Untuk variabel independen, struktur modal yang diukur dengan Debt to Equity Ratio (DER) yang merupakan perbandingan antara total hutang dengan modal sendiri mempunyai nilai minimum sebesar 0,728 , nilai maksimum sebesar 4 , 483 dengan nilai rata-rata sebesar 1,967 dan standar deviasi sebesar 1,464.

3. Untuk variabel independen, ukuran perusahaan yang diukur dengan size yang merupakan besaran perusahaan yang ditunjukan dengan posisi jumlah total aset, mempunyai nilai minimum sebesar 12,001, nilai maksimum sebesar 12.498 dengan nilai rata-rata sebesar 12,498 dan standar deviasi sebesar 0,274.

4. Untuk variabel independen likuiditas yang diukur dengan rasio lancar (current ratio) yang merupakan perbandingan antara aset lancar dengan kewajiban lancar, mempunyai nilai minimum sebesar 1,382, nilai maksimum sebesar 3,333 dengan nilai rata-rata sebesar 2,121 dan standar deviasi sebesar 0,566.

5. Untuk variabel dependent, profitabilitas yang diukur dengan retur on assets (ROA) yang merupakan perbandingan antara laba bersih setelah pajak dengan total aset mempunyai nilai minimum sebesar 0.041 , nilai maksimum sebesar 0,334 dengan nilai rata-rata sebesar 0,149 dan standar deviasi sebesar 0.936 .

\subsection{Pengujian Hipotesis}

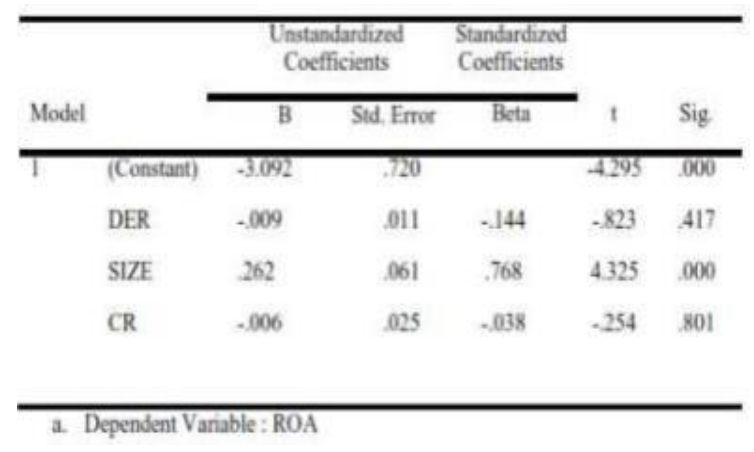

Pengaruh DER terhadap profitabilitas

Berdasarkan tabel di atas dapat diketahui bahwa dari hasil perhitungan t_hitung untuk variabel struktur modal yang diproksikan dengan Debt Equity Ratio (DER) sebesar 0.823 dengan tingkat signifikansi $0,417>$ 0,05 . Dapat disimpulkan bahwa H_o diterima dan H_1 ditolak. Artinya bahwa hipotesis pertama variabel struktur modal (DER) secara persial tidak ada pengaruh yang signifikan negatif terhadap profitabilitas (ROA), sehingga hipotesis yang diajukan ditolak. Jadi DER merupakan faktor yang tidak dapat menurunkan ROA perusahaan.

Hasil analisis regresi yang telah dilakukan menunjukkan, bahwa secara persial DER tidak berpengaruh positif signifikan terhadap profitabilitas.

\section{Pengaruh Size terhadap profitabilitas}

Berdasarkan tabel di atas dapat diketahui bahwa dari hasil perhitungan t_hitung untuk variabel ukuran perusahaan yang diproksikan dengan Size sebesar 4.325 dengan tingkat signifikansi $0,000<0,05$. Dapat disimpulkan bahwa H_o ditolak dan H_2 diterima. Artinya bahwa variabel ukuran perusahaan (Size) secara persial ada pengaruh positif signifikan terhadap profitabilitas (ROA). sehingga hipotesis yang diajukan diterima.

\section{Pengaruh CR terhadap profitabilitas}

Berdasarkan tabel di atas dapat diketahui bahwa dari hasil perhitungan t_hitung untuk variabel likuiditas yang diproksikan dengan Current Ratio (CR) sebesar -0.254 dengan tingkat signifikansi $0,801>0,05$, sehingga dapat dikatakan bahwa H_o diterima dan H_3 ditolak. Artinya bahwa variabel likuiditas (CR) secara persial tidak ada 
pengaruh yang signifikan dan negatif terhadap profitabilitas (ROA). Sehingga hipotesis yang diajukan ditolak.

\section{KESIMPULAN}

Nilai t_hitung untuk variabel struktur modal (DER) sebesar -0.823 dengan tingkat signifikansi $0,417>5 \%$ atau 0,05 ; sehingga dapat dikatakan bahwa tidak ada pengaruh yang signifikan dan negatif antara struktur modal (DER) terhadap profitabilitas (ROA) secara parsial. Dengan demikian struktur modal (DER) tidak berpengaruh terhadap profitabilitas (ROA).

Nilai t_hitung untuk variabel ukuran perusahaan (Size) sebesar 4.325 dengan tingkat signifikansi $0,000<0,05$; sehingga dapat dikatakan bahwa ada pengaruh yang signifikan dan positif antara ukuran perusahaan (Size) terhadap profitabilitas (ROA) secara parsial. Dengan demikian ukuran perusahaan (Size) berpengaruh terhadap profitabilitas (ROA).

Nilai t_hitung untuk variabel likuiditas (CR) sebesar sebesar -0.254 dengan tingkat signifikansi $0,801>0,05$; sehingga dapat dikatakan bahwa tidak ada pengaruh yang signifikan dan negatif antara variabel likuiditas (CR) terhadap profitabilitas (ROA) secara parsial. Dengan demikian variabel likuiditas (CR) tidak berpengaruh terhadap profitabilitas (ROA).

\section{DAFTAR PUSTAKA}

Ambarwati, N. S., Yuniarta, G. A., \& Sinarwati, N. K. (2015). Pengaruh Modal Kerja, Likuiditas, Aktivitas dan Ukuran Perusahaan Terhadap Profitabilitas Pada perusahaan Manufaktur yang Terdaftar di BEI. Jurusan Akuntansi Program S1, 3 (1), 1-11.

Amdani, \& Desnerita. (2015). Pengaruh Struktur Modal dan Working Capital Turnover Terhadap Profitabilitas (Studi Empiris pada Pembayaran Pajak Perusahaan yang Diperiksa Oleh Kantor Pelayanan Pajak Madya Jakarta Pusat).
Jurnal Akuntansi, XIX.(3).

Aprilia, Rosella \& Effendi, Bahtiar (2019). Pengaruh Pergantian Manajemen, Kepemilikan Publik dan Financial Distress terhadap Auditor Switching. STATERA: Jurnal Akuntansi dan Keuangan, 1(1), 61-75.

Arifin, A. (2007). Membaca Saham. Yogyakarta: Salemba Empat.

Bonatua, B. H., Suhadak, \& Endang, M.W. (2015). Pengaruh Struktur Modal Terhadap Profitabilitas (Studi Perusahaan Manufaktur Sub Sektor Food and Beverage yang Listed di BEI Periode 2010-2013). Jurnal Administrasi Bisnis (JAB), 2 (2), 1-7.

Chen, S., \& Oetomo, H. W. (2015). Pengaruh Leverage, Likuiditas dan Perputaran Modal Kerja terhadap Profitabilitas. Jurnal Ilmu dan Riset Manajemen, 4 (10), 1-21.

Dewi, N. K., Cipta, W., \& Kirya, I. K. (2015). Pengaruh LDR, LAR, DER dan CR Terhadap ROA. e-Journal Bisma Universitas Pendidikan Ganesha, 1-10.

Douglas, A. Lind. (2011). Statistical Techniquues in Business and Economics, edisi limabelas.

Effendi, Bahtiar. (2019). Kualitas Audit, Kondisi Keuangan, Ukuran Perusahaan dan Penerimaan Opini Audit Going Concern. Owner: Jurnal Riset dan Akuntansi, 3(1), 9-15.

Effendi, Bahtiar. (2019). Profitabilitas, Solvabilitas dan Audit Delay Pada Perusahaan Consumer Goods yang Terdaftar di BEI. Owner: Jurnal Riset dan Akuntansi, 2(2), 100-108.

Effendi, Bahtiar. (2019). Kondisi Keuangan, Opinion Shopping dan Opini Audit Going Concern pada Perusahaan Pertambangan yang Terdaftar di BEI. STATERA: Jurnal Akuntansi dan Keuangan, 1(1), 34-46.

Effendi, Bahtiar. (2018). Pengaruh Ukuran Perusahaan dan Ukuran KAP terhadap Audit Delay. At Negotium Procuratio: Jurnal Bisnis dan Manajemen, 4(1), 111.

Effendi, Bahtiar. (2018). Ukuran Perusahaan, Dewan Komisaris dan Environmental Disclosure. Jurnal Riset Akuntansi Tirtayasa, 3 (1), 1-19. 
Effendi, Bahtiar \& Khamdevi, Muhammar. (2017). Tingkat Efisiensi Energi Bangunan Hijau dan Profitabilitas Manufaktur. MARKA (Media Arsitektur dan Kota): Jurnal Ilmiah Penelitian, l(1), 19-24.

Effendi, Bahtiar. (2017). Ukuran Perusahaan, Jumlah Rapat Dewan Komisaris dan Environmental Disclosure di Indonesia. At Negotium Procuratio: Jurnal Bisnis dan Manajemen, 3(2), 13-25.

Fitri, Linda Rahmawati. (2009). Pengaruh Current Ratio, Inventory Turnover, dan Debt To Equity Ratio Return On Asset. Skripsi tidak diterbitkan. Universitas Negeri Malang, Malang.

Hadri, K., \& Yuke , P. (2005). Faktor-Faktor yang Mempengaruhi Struktur Modal Perusahaan Manufaktur Go Public di Bursa Efek Jakarta . Sinergi Kajian Bisnis dan Manajemen, edisi khusus on finance, 1-15.

Halim, A. (2007). Akuntansi Keuangan Daerah . Jakarta: Salemba Empat.

Haninun, \& Angelina, F. (2016). Pengaruh Struktur Modal Terhadap Profitabilitas Pada Perusahaan Manufaktur yang Terdaftar di BEI Periode 2011-2013. Jurnal Akuntansi \& Keuangan, 7(1), 7386.

Harahap, Sofyan Syafri. (2015). Analisis Kritis atas Laporan Keuangan. Jakarta: PT Raja Grafindo Persada.

Hornes, J. V., \& John M, W. J. (2009) Prisip-Prinsip Manajemen Keuangaan, edisi Pertama. Jakarta: Salemba Empat.

Husnan, Suad. (2013). Manajemen Keuangan Edisi Keempat. BPFE, Yogyakarta.

Iskandar, T. E., \& E, D. (2014). Pengaruh Perputaran Modal Kerja, Struktur Modal dan Likuiditas Terhadap Profitabilitas Perusahaan Industri Chemical di BEI. JOM FEKON, 1. (2).

Kasmir. (2012). Analisa Laporan Keuangan . Jakarta : Rajawali Pers.

Kesuma, A. (2009). Analisis Faktor yang Mempengaruhi Struktur Modal serta Pengaruhnya Terhadap Harga Saham Perusahaan Real Estate yang Go-Public Di BEI. Jurnal Manajemen \& Kewirausahaan. Vol. II. No. 1/Hal: 3845.

Larasati, E. (2011). Pengaruh Kepemilikan
Manajerial, Kepemilikan Institusional dan Sebaran Kepemilikan Terhadap Kebijakan Hutang Perusahaan Ditinjau dari Teori Keagenan Emisi .

Magaretha, F., (2014). Dasar-Dasar Manajemen Keuangan. Dian Rakyat.

Magaretha, F., \& Khairunisa.(2016). Pengaruh Struktur Modal dan Likuiditas Terhadap Profitabilitas Pada Usaha Kecil Dan Menengah di Indonesia. Jurnal Manajemen Bisnis, 11 (2), 129-140.

Munawir. (2004). Analisa Laporan Keuangan, edisi keempat, cetakan ketiga belas. Yogyakarta: Liberty.

Nawalani, A. P., \& Lestari, W. (2015). Pengaruh Modal kerja terhadap profitabilitas pada perusahaan food and beverages di Bursa Efek Indonesia. Journal of Business and Banking, 5 (1), $1-14$.

Noor, A. s., \& Lestari, B. (2016). Analisis Pengaruh Efesiensi Modal Kerja, Likuiditas dan solvabilitas Terhadap Profitabilitas pada Industri Barang Konsumsi Di BEI. Jurnal SpreadOktober 2012, 2 (2), 133-138.

Nugroho, E. (2011). Pertumbuhan Penjualan, Perputaran Modal Kerja, Ukuran Perusahaan dan Leverage Terhadap Profitabilitas Perusahaan (Studi pada Perusahaan Manufaktur yang Terdaftar pada BEI pada Tahun 2005 - 2009). 177.

Prof. Dr. H. Imam Ghozali, M. A. (2006). Aplikasi Analisis Multivariate dengan Program SPSS. Semarang: Badan Penerbit Universitas Diponegoro.

Putra, A. W., \& Badjra, I. B. (2015). Penagaru leverage, pertumbuhan penjualan dan ukuran perusahaan terhadap profitabilitas. E-Jurnal Manajemen Unud, 4(7), 1-16.

Rahmah, A. M., Cipta, W., \& Yudiaatmaja, F. (2016). Pengaruh Likuiditas, Solvabilitas dan aktivitas Terhadap Profitabilitas Pada Perusahaan Otomotif yang Terdaftar di BEI. e-Journal Bisma Universitas Pendidikan Ganesha, Jurusan Manajemen Volume 4, 1-8.

Ratnasari, L., \& Budiyanto. (2016). Pengaruh Leverage, Likuiditas, Ukuran Perusahaan Terhadap Profitabilitas Pada Perusahaan Otomotif di BEI. Jurnal Ilmu dan Riset 
Manajemen, 5 (6), 1-15.

Remeinda, V., Murni, S., \& Saerang, i. (2016). Analisis Pengaruh modal Kerja Terhadap Profitabilitas Pada Industri Telekomonikasi di Indonesia. Jurnal Berkala Ilmiah Efisiensi, Volume 16 No. 03, 207-218.

Rifai, M., Arifati, R., \& Magdalena , M. (2013). Pengaruh Ukuran Perusahaan, Struktur Modal dan Pertumbuhan Perusahaan Terhadap Profitabilitas Studi Pada Perusahaan Manufaktur di BEI Tahun 2010-2012. 1-8.

Riyanto, B. (2001). Dasar-Dasar Pembelanjaan Perusahaan. edisi Keempat. BPFE Yogyakarta.

Rosyadah, F., Suhadak, \& Darminto. (2012). Pengaruh Struktur Modal Terhadap Profitabilitas (Studi Pada Perusahaan Real Estate and Property Yang Terdaftar di Bursa Efek Indonesia (BEI) Periode 2009 - 2011). 1-11.

Sariyana, B. M., Yudiatmaja, F., \& Suendra, I. W. (2016). Pengaruh Perputaran Modal Kerja dan Likuiditas Terhadap Perusahaan Profitabilitas (Studi Pada Perusahaan Food and Beverages). eJournal Bisma Universitas Pendidikan Ganesha, Jurusan Manajemen, 4, 1-10.
Sekarwigati, Mega \& Effendi, Bahtiar. (2019). Pengaruh Ukuran Perusahaan, Profitabilitas, dan Likuiditas terhadap Corporate Social Responsibility Disclosure. STATERA: Jurnal Akuntansi dan Keuangan, 1(1), 16-33.

Sugiyono. (2010). Metode Penelitian Pendidikan Pendekatan Kuantitatif, Kualitatif dan $R$ \& $D$. Bandung: Alfabeta.

Sjahrial, D. (2009). Manajemen Keuangan. Jakarta: Wacana Media.

Syarib, M., \& Prijati. (2016). Pengaruh Struktur Modal dan WCTO Terhadap Profitabilitas perusahaan Semen di BEI. Jurnal Ilmu dan Riset Manajemen, 5 (12), 1-16.

Ulfah, P. A., \& Sapari. (2017). Pengaruh perputaran Modl Kerja Terhadap Profitabilitas Pada Perusahaan Makanan dan Minuman. Jurnal Ilmu dan Riset Akuntansi, Volume 6, Nomor 6, 1-20.

Weston , J., \& F.T, B. (2009). Dasar-Dasar Manajemen Keuangan, edisi kesembilan. Erlangga. Jakarta 